\title{
Signifikansi Komponen Pasang Surut Perairan Dangkal di Sungai Kapuas Kecil
}

Junita Saria ${ }^{*}$, Muliadia, Arie Antasari Kushadiwijayanto ${ }^{b}$

aProgram Studi Fisika, FMIPA Universitas Tanjungpura, bProgram Studi Ilmu Kelautan, FMIPA Universitas Tanjungpura, Jalan Prof. Dr. Hadari Nawawi, Pontianak, Indonesia

*Email : junitasari911@gmail.com

\begin{abstract}
Abstrak
Penelitian tentang signifikansi komponen pasang surut perairan dangkal telah dilakukan di Sungai Kapuas Kecil. Data yang digunakan dalam penelitian ini merupakan data sekunder dari tiga stasiun yang terletak di Jungkat, TPI Sungai Rengas dan BMKG Maritim. Analisis data pasang surut dari ketiga stasiun dilakukan menggunakan program t_tide untuk mendapat komponen pasang surut. Berdasarkan hasil penelitian didapatkan 16 komponen pasang surut di perairan dangkal yang terdapat di Sungai Kapuas Kecil. Hasil nilai amplitudo di setiap stasiun yang paling dominan adalah komponen $\mathrm{MK}_{3}$ dengan nilai 0,0353 meter di stasiun TPI. Komponen dengan nilai signifikan terbanyak terdapat di stasiun 2 dan 3 yang berlokasi di TPI Sungai Rengas dan BMKG Maritim. Nilai signifikan yang terkecil terdapat di stasiun 1 yang berlokasi di Muara Jungkat.
\end{abstract}

\section{Kata Kunci: Pasang Surut, Sungai Kapuas Kecil, T_Tide, Amplitudo, Fase, Komponen}

\section{Latar Belakang}

Sungai Kapuas terletak di Provinsi Kalimantan Barat dan merupakan sungai terpanjang di Indonesia [1]. Sungai Kapuas memiliki panjang kira-kira 1.143 $\mathrm{km}$ [2] dan menjadi satu di antara sumber mata pencaharian bagi masyarakat di sepanjang aliran sungai. Contoh kegunaan sungai kapuas adalah sebagai sarana transportasi, penangkapan ikan maupun sarana wisata air. Aktifitas masyarakat setempat tidak dapat dipisahkan dari fenomena pasang surut baik secara langsung maupun tidak langsung, dan dengan adanya data pasang surut diharapkan dapat membantu masyarakat dalam kegiatan sehari-hari.

Data pasang surut dipisahkan berdasarkan besaran komponen pasang surut (pasut) atau konstanta harmonik. Konstanta harmonik merupakan besaran amplitudo dan fase dari tiap komponen pasut. Pasut di perairan dangkal merupakan superposisi dari pasut yang ditimbulkan oleh faktor astronomi, faktor meteorologi, dan pasut yang ditimbulkan oleh pengaruh berkurangnya kedalaman perairan atau yang disebut dengan pasut perairan dangkal (shallow water tides).

Salah satu komponen perairan dangkal adalah $\mathrm{M}_{4}$, konstanta ini merupakan hasil dari komponen $\mathrm{M}_{2}$ yang telah mengalami perubahan bentuk sehingga memiliki kecepatan sudut dua kali lipat dibandingkan $\mathrm{M}_{2}$. Komponen $\mathrm{M}_{2}$ merupakan amplitudo pasang surut ganda utama yang disebabkan oleh gaya tarik bulan. Komponen pasang surut perairan dangkal akan meningkat pengaruhnya secara signifikan pada daerah pesisir, sehingga komponen ini dapat mempresentasikan keadaan sebenarnya secara akurat.
Penelitian tentang konstribusi konstanta harmonik di perairan dangkal di Pulau Jawa pernah dilakukan sebelumnya. Penelitian tersebut memperlihatkan Pengaruh signifikan komponen pasang surut di perairan dangkal. Hasil penelitian tersebut menunjukkan bahwa sisi Utara Pulau Jawa memiliki persentase kontribusi konstanta pasang surut perairan yang sangat luas dan lebih banyak terdistorsi sehingga menghasilkan konstanta pasang surut perairan dangkal signifikan lebih banyak dan kontribusi yang lebih besar terhadap pembentukan pasang surut [3]. Selain itu, penelitian tentang karakteristik perambatan pasang surut di perairan dalam estuari Kapuas Kecil telah dilakukan [4]. Hasil penelitianya menunjukkan nilai amplitudo dan fase untuk masing-masing komponen utama pasang surut bervariasi pada setiap stasiun di perairan dalam dan terjadinya perubahan gelombang pasang surut disebabkan adanya pengaruh bentuk muara sungai dan gesekan dasar perairan.

Berdasarkan penelitian sebelumnya, maka penelitian ini lebih berkonsentrasi membahas signifikansi komponen pasang surut di perairan dangkal Sungai Kapuas Kecil karena mengingat besarnya pengaruh pasang surut dalam segala aktivitas di Sungai Kapuas Kecil serta perannya dalam dinamika di sungai.

Penelitian ini bertujuan untuk mengetahui komponen perairan dangkal dengan nilai amplitudo dan fase setiap stasiun.

\section{Metodologi \\ 2.1 Data}

Data yang digunakan dalam penelitian ini adalah data sekunder yang telah diperoleh dari hasil pengukuran yang dilakukan oleh Lindawati [4] 


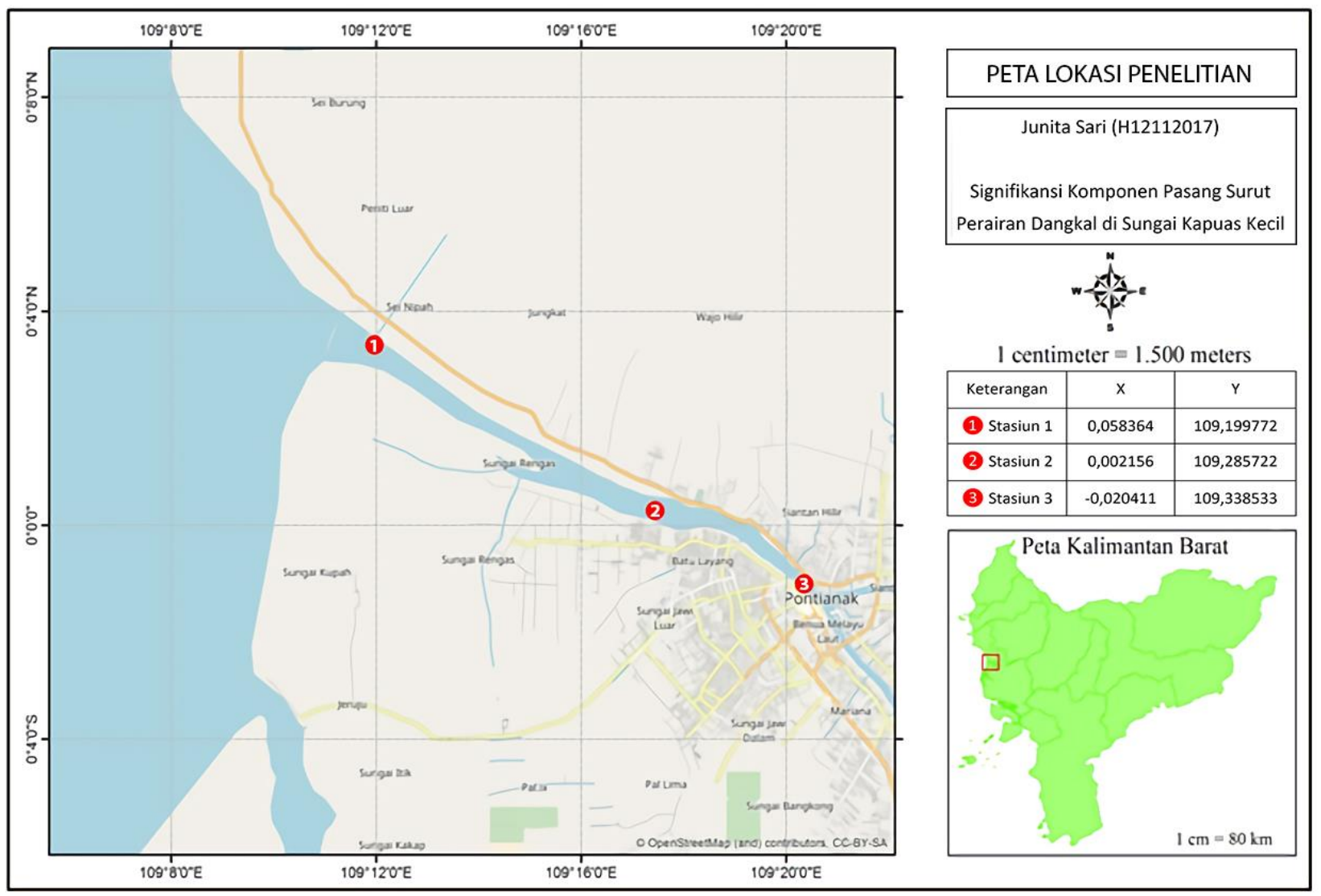

Gambar 1. Lokasi Data Penelitian

Tabel 1. Koordinat Titik Pengambilan

\begin{tabular}{ccc}
\hline No & Nama Titik & Koordinat Pengambilan Data \\
\hline 1 & Jungkat & $0^{\circ} 3^{\prime} 30.11^{\prime \prime} \mathrm{LU} 109^{\circ} 11^{\prime} 59.18^{\prime \prime B} \mathrm{BT}$ \\
2 & TPI (Sungai Rengas) & $0^{\circ} 0^{\prime} 7.76^{\prime \prime} \mathrm{LU} 109^{\circ} 17^{\prime} 8.60^{\prime \prime} \mathrm{BT}$ \\
3 & BMKG & $0^{\circ} 1^{\prime} 13.48^{\prime \prime} \mathrm{LS} 109^{\circ} 20^{\prime} 18.72^{\prime \prime} \mathrm{BT}$ \\
\hline
\end{tabular}

\subsection{Analisis Data}

Analisis data yang dilakukan pada penelitian ini yaitu:

1. Menganalisis komponen pasang surut perairan dangkal di setiap stasiun.

2. Menganalisis model amplitudo dan fase di setiap stasiun dalam diagram batang.

3. Menganalisis komponen pasang surut perairan dangkal yang signifikan di setiap stasiun.

\subsection{Pengolahan Data}

Proses pengolahan data dimulai dengan memindahkan data pasang surut yang tercatat di alat ke dalam excel. Sebelum dilakukan analisis dengan program t_tide data elevasi mengalami anomali diganti dengan (NaN) seperti yang dilakukan [5]. Setelah itu data pasang surut diolah dengan menggunakan program t_tide. Program t_tide ini diproses dengan menggunakan MATLAB. Hasil keluaran dari $t_{-}$tide berupa komponen pasang surut yang nantinya akan di analisis sebagai hasil.
Dari hasil pengolahan t_tide didapat komponen pasang surut utama (komponen pasang surut perairan dalam dan perairan dangkal). Pada penelitian ini hanya membahas komponen perairan dangkal yang terdapat di Sungai Kapus terdiri dari 16 komponen yaitu $\mathrm{MO}_{3}, \mathrm{MK}_{3}, \mathrm{SK}_{3}, \mathrm{MN}_{4}, \mathrm{M}_{4}, \mathrm{MS}_{4}, \mathrm{~S}_{4}, \mathrm{SN}_{4}$ $2 \mathrm{MK}_{5}, 2 \mathrm{SK}_{5}, 2 \mathrm{MN}_{6}, \mathrm{M}_{6}, 2 \mathrm{MS}_{6}, 2 \mathrm{SM}_{6}, 3 \mathrm{MK}_{7}$ dan $\mathrm{M}_{8}$.

Nilai amplitudo dan fase dari pengolahan $t_{-}$tide akan digunakan untuk memvisualisasikan pasang surut perairan dangkal di Sungai Kapuas Kecil dalam bentuk diagram batang.

Konstanta harmonik signifikan merupakan komponen-komponen yang mendapatkan nilai paling tinggi diantara total perolehan komponen harmonik seluruhnya, dimana perbandingan nilai amplitudonya lebih besar dari pada amplitudo errornya. Nilai amplitudo errornya dinyatakan dalam SNR (signal to noise ration) [6]. Untuk menentukan signifikan atau tidaknya konstanta pasang surut menggunakan SNR yang diporoleh dari program 
t_tide. SNR > 1 akan dinyatakan sebagai konstanta harmonik yang signifikan.

Nilai SNR dapat ditentukan menggunakan persamaan berikut [7]:

$$
S N R=\left(\frac{A i}{\text { Aerrori }}\right)^{2}
$$

\subsection{Diagram Alir}

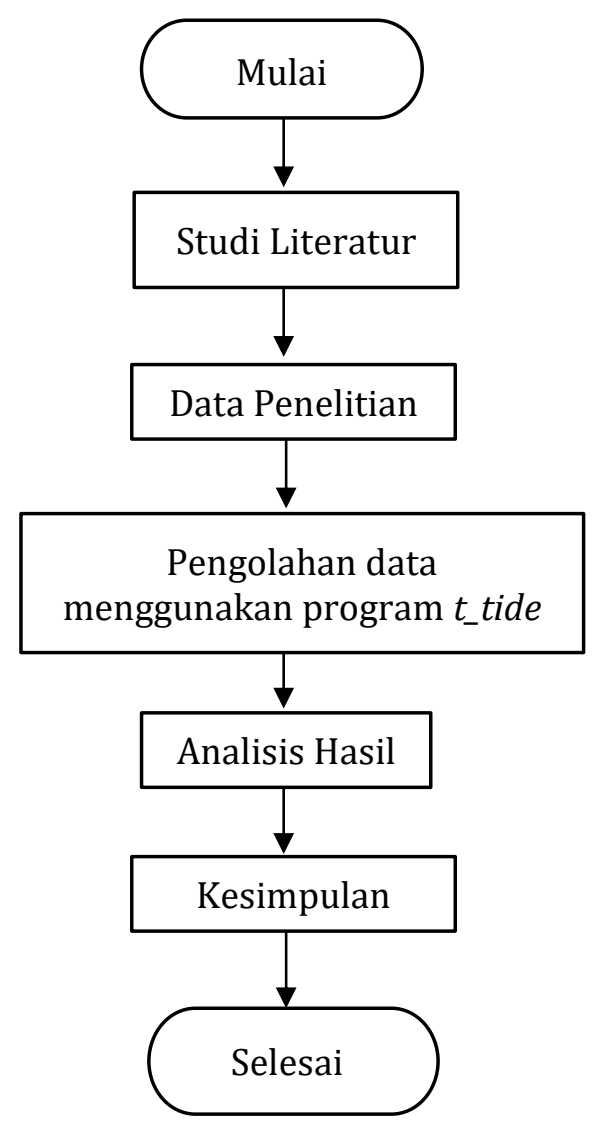

Gambar 2. Bagan Alir Prosedur Penelitian

\section{Hasil dan Pembahasan}

\subsection{Amplitudo Pasang Surut Perairan Dangkal}

Berdasarkan hasil penelitian menunjukkan nilai amplitudo pada setiap stasiun mempunyai nilai bervariasi. Hasil perhitungan amplitudo yang
Keterangan:

SNR : Signal to noise ration

$\mathrm{A}_{i} \quad$ : Amplitudo konstanta ke-i

A $_{\text {error }}$ : : Amplitudo error konstanta ke-i

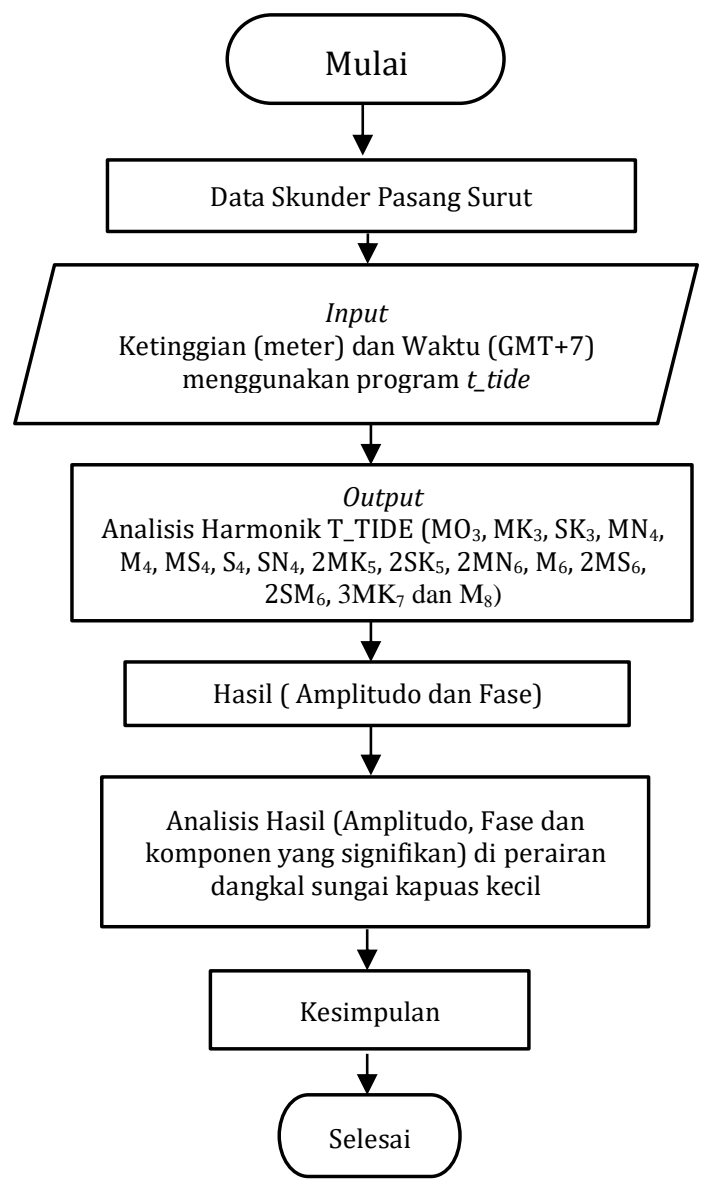

Gambar 3. Diagram Alir Pengolahan Data

meliputi stasiun 1 sampai 3 dapat divisualisasikan dalam bentuk diagram batang seperti Gambar 4. Meramalkan pasang surut diperlukan data amplitudo masing-masing komponen pembangkit pasang surut, sehingga diperlukan analisis harmonik dengan program t_tide. 


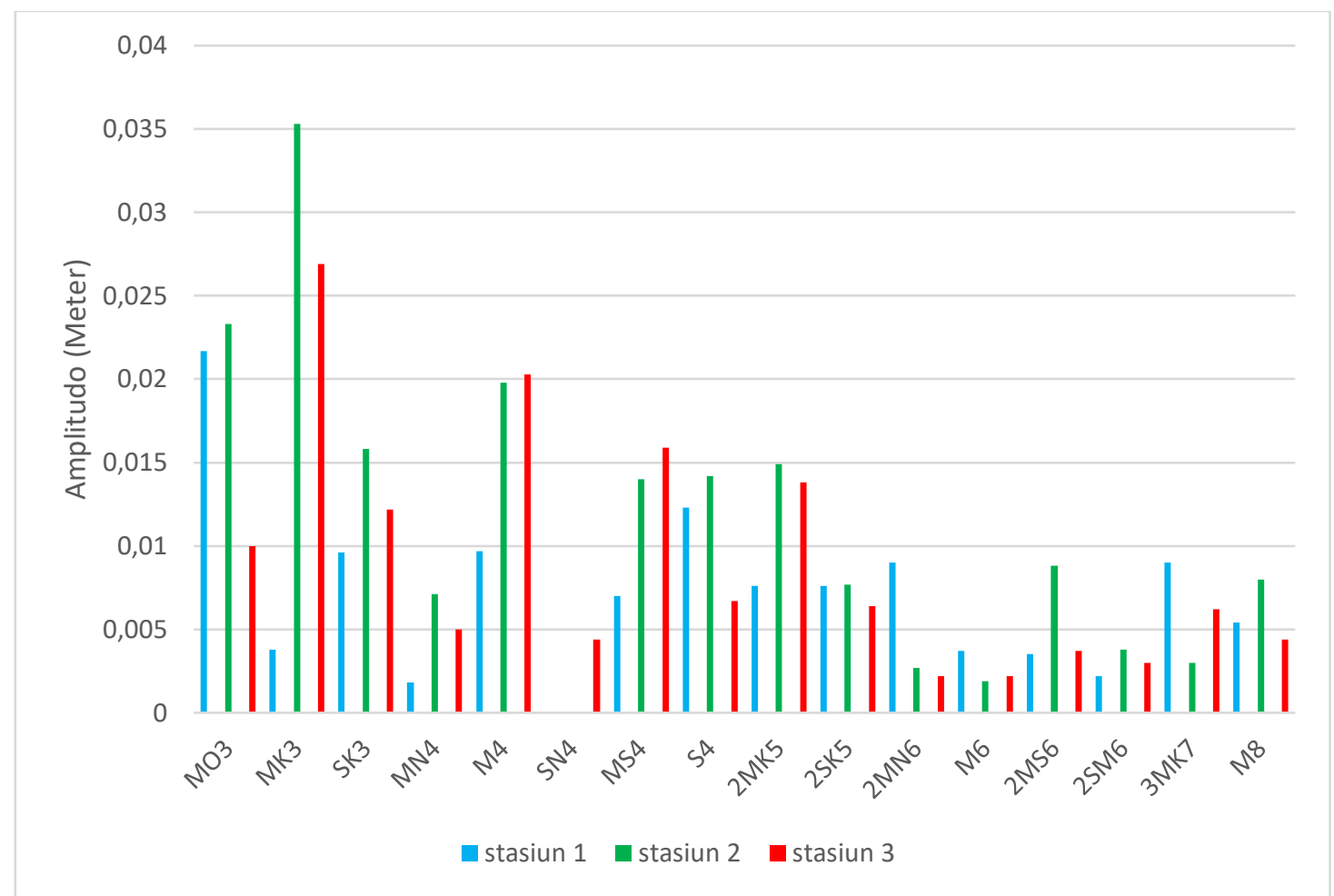

Gambar 4. Diagram Batang Amplitudo Pasang Surut Perairan Dangkal Pada setiap Stasiun

Hasil analisis harmonik pada stasiun 1 dapat dilihat pada (Gambar 4) yang ditunjukkan dengan garis berwarna biru. Nilai komponen pasang surut yang paling dominan di perairan dangkal pada stasiun 1 adalah $\mathrm{MO}_{3}$ dengan nilai amplitudo sebesar 0,0217 meter yang merupakan komponen tertinggi di Jungkat. Dominansi $\mathrm{MO}_{3}$ merupakan nilai amplitudo yang paling tinggi diantara komponen lainnya. Hal ini terjadi karena adanya interaksi antara komponen $\mathrm{M}_{2}$ dengan $\mathrm{O}_{1}$ yang dipengaruhi oleh gaya gravitasi bulan dan deklinasi bulan. Meskipun ukuran bulan lebih kecil dari matahari, namun gaya tarik gravitasi bulan dua kali lebih besar daripada gaya tarik matahari dalam membangkitkan pasang surut laut karena jarak bulan lebih dekat daripada jarak matahari ke bumi [8]. Selain gaya gravitasi bulan, sudut deklinasi bulan juga berpengaruh terhadap pasang surut. Hal ini disebabkan karena lintasan revolusi bulan mengelilingi bumi tidak sejajar dengan garis khatulistiwa. Sudut deklinasi dinyatakan dalam derajat yang merupakan lintang dari bumi. Sudut positif untuk di posisi sebelah utara khatulistiwa dan sudut negatif untuk daerah disebelah selatan khatulistiwa [9].

Hasil analisis harmonik di stasiun 2 dilihat pada (Gambar 4). Nilai amplitudo pada stasiun 2 ditunjukkan dengan garis berwarna hijau. Komponen pasang surut perairan dangkal yang dominan pada stasiun 2 adalah $\mathrm{MK}_{3}$. Nilai amplitudo yang dihasilkan sebesar 0,0353 meter yang merupakan komponen tertinggi di TPI Sungai Rengas. Hal ini terjadi karena adanya interaksi antara bulan dan matahari, dimana interaksi ini berpengaruh terhadap pasang surut dengan perubahan jarak bulan akibat lintasan yang berbentuk elips. Sebagaimana yang dikemukakan oleh seorang ahli matematika dan astronomi dari jerman bernama johan kepler (1571-1630) bahwa planet tidak bergerak dengan kelajuan konstan tetapi bergerak lebih cepat ketika berada dekat dengan matahari [10].

Hasil analisis harmonik di stasiun 3 dapat dilihat pada (Gambar 4). Nilai amplitudo pada stasiun 3 ditunjukkan dengan garis berwarna merah. Nilai komponen pasang surut pada stasiun 3 menghasilkan komponen pasang surut perairan dangkal yang dominan adalah komponen $\mathrm{MK}_{3}$, dimana nilai amplitudo yang dihasilkan sebesar 0,0269 meter yang merupakan komponen tertinggi di BMKG Maritim. Hal ini terjadi karena adanya interaksi antara bulan dan matahari, dimana interaksi ini berpengaruh terhadap pasang surut dengan perubahan jarak bulan akibat lintasan yang berbentuk elips, sebagaimana yang dijelaskan dalam hukum Kepler.

\subsection{Fase Pasang Surut Perairan Dangkal}

Meramalkan pasang surut diperlukan data fase masing-masing komponen pembangkit pasang surut, sehingga diperlukan analisis harmonik dengan program $t$ tide. Berdasarkan hasil perhitungan yang meliputi stasiun 1 sampai 3 dapat divisualisasikan dalam bentuk diagram batang seperti pada (Gambar 5). 


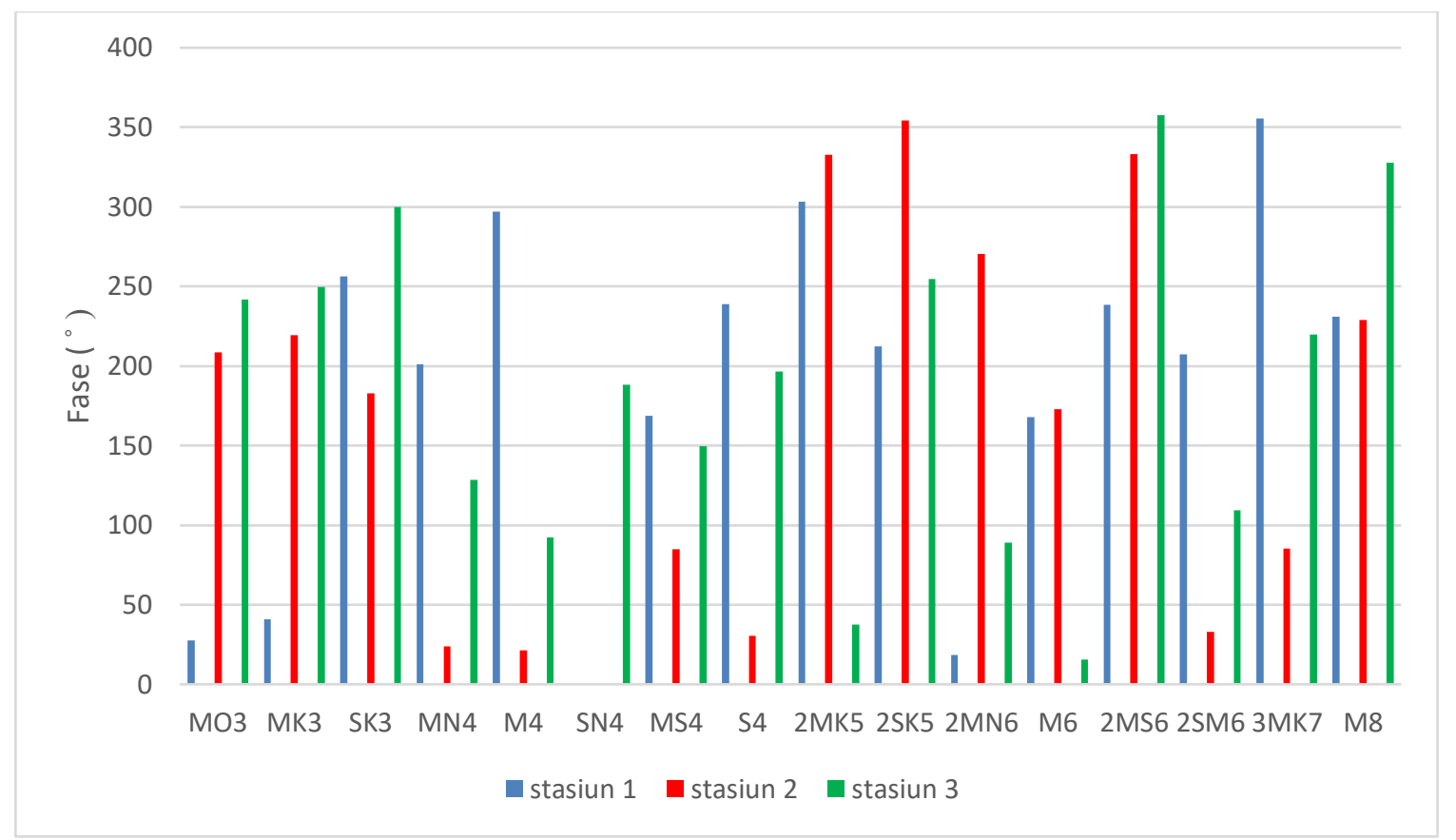

Gambar 5. Diagram Batang Fase Pasang Surut Perairan Dangkal Pada setiap Stasiun

Hasil analisis harmonik pada stasiun 1 ditunjukkan pada (Gambar 5) dengan garis berwarna biru. Komponen pasang surut perairan dangkal yang memiliki nilai fase paling tinggi di stasiun 1 adalah $3 \mathrm{MK}_{7}$ dengan nilai derajat kemiringan $355,71^{\circ}$ yang terdapat di Muara Jungkat. Komponen ini dipengaruhi oleh gaya gravitasi bulan dan adanya deklinasi matahari dan bulan. Bulan memberikan gaya tarik (gravitasi) yang lebih besar dibanding matahari. Hal ini disebabkan karena masa bulan lebih kecil dari matahari, tetapi posisinya lebih dekat ke bumi. Gaya-gaya ini mengakibatkan air laut, yang menyusun $71 \%$ permukaan bumi, menggelembung pada sumbu yang menghadap ke bulan [11]. Selain gaya tarik bulan, deklinasi bulan dan matahari sangat berpengaruh terhadap komponen ini. Hal ini disebabkan karena deklinasi bulan mengelilingi bumi tidak sejajar dengan garis khatulistiwa [9]. Sedangkan deklinasi matahari adalah jarak posisi matahari dengan ekuator (khatulistiwa) langit diukur melalui lingkaran waktu atau lingkaran deklinasi dan dihitung dengan derajat menit dan detik. Apabila deklinasi suatu benda langit berada di utara khatulistiwa yang bertanda positif $(+)$ dan apabila berada langit berada di sebelah selatan khatulistiwa bertanda negatif $(-)$, maka kedua benda tersebut tegak lurus pada lingkaran khatulistiwa [13].

Hasil analisis harmonik pada stasiun 2 ditunjukkan pada (Gambar 5) dengan garis berwarna merah. Fase pasang surut perairan dangkal pada stasiun 2 memiliki kemiringan tertinggi adalah $2 \mathrm{SK}_{5}$. Komponen $2 \mathrm{SK}_{5}$ merupakan fase tertinggi dengan nilai sebesar $354,51^{\circ}$. Hal ini terjadi karena gaya tarik matahari serta dipengaruhi oleh deklinasi matahari dan bulan. Deklinasi matahari dan bulan sangat berpengaruh terhadap komponen ini, karena deklinasi bulan mengelilingi bumi tidak sejajar dengan garis khatulistiwa sehingga posisi bulan mempengaruhi pasang surut dan jarak posisi matahari dengan ekuator.

Hasil analisis harmonik pada stasiun 3 ditunjukkan pada (Gambar 5) dengan garis berwarna hijau. Stasiun 3 memiliki nilai komponen pasang surut perairan dangkal yang tertinggi adalah $2 \mathrm{MS}_{6}$, yang memiliki nilai fase pasut sebesar $357.46^{\circ}$. hal ini terjadi karena adanya pengaruh gaya tarik bulan dan gaya tarik matahari membuat komponen ini memiliki nilai fase pasang surut perairan dangkal tertinggi pada stasiun tiga.

\subsection{Komponen Perairan Dangkal Signifikan}

Pengolahan data menggunakan program t_tide juga menghasilkan komponen amplitudo error, dimana komponen ini mendukung untuk menentukan nilai signifikan komponen pasang surut perairan dangkal. Menentukan signifikan atau tidaknya signifikan komponen pasang surut perairan dangkal dapat menggunakan persamaan 3.1 dengan nilai $>1$ akan dinyatakan sebagai konstanta harmonik yang signifikan. Hasil perhitungan dari persamaan 3.1 kemudian divisualisasikan dalam bentuk grafik diagram batang di setiap stasiun masing-masing.

Nilai komponen signifikan dan tidak signifikan di stasiun 1 dapat dilihat pada (Gambar 6). Komponen yang signifikan pada stasiun 1 berjumlah 8 komponen yaitu $\mathrm{MO}_{3}, \mathrm{M}_{4}, \mathrm{~S}_{4}, 2 \mathrm{MK}_{5}, 2 \mathrm{SK}_{5}, 2 \mathrm{MN}_{6}, 3 \mathrm{MK}_{7}$ dan $\mathrm{M}_{8}$ dengan nilai yang bervariasi setiap komponenya. Komponen yang tidak signifikan pada stasiun 1 terdapat 7 komponen yaitu $\mathrm{MK}_{3}, \mathrm{SK}_{3}, \mathrm{MN}_{4}$, $\mathrm{MS}_{4}, \mathrm{M}_{6}, 2 \mathrm{MS}_{6}, 2 \mathrm{SM}_{6}$ dengan nilai yang bevariasi 


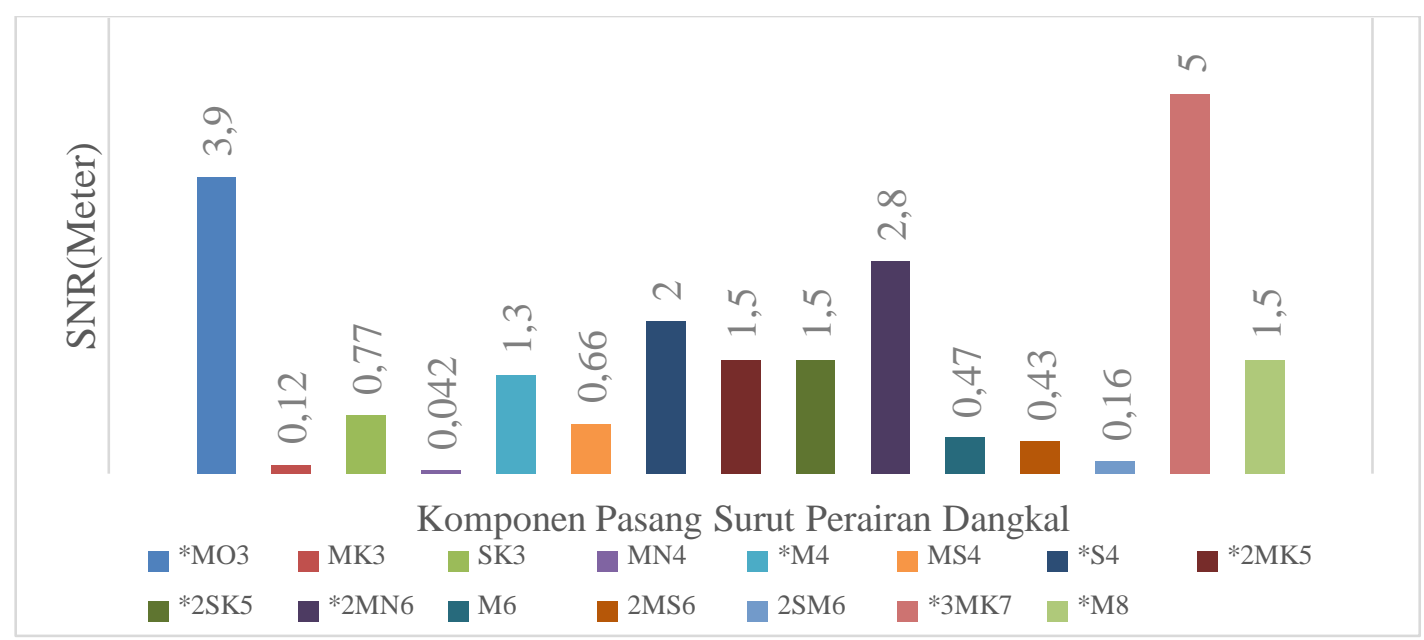

Gambar 6. Komponen pasang surut perairan dangkal signifikan dan tidak signifikan di Muara Jungkat.

setiap komponen pasang surut peraiaran dangkal. Hal ini terjadi karena di stasiun 1 lebih banyak mengalami gangguan/ error sehingga komponen tidak signifikanya lebih banyak dari stasiun 2 dan 3 .

Nilai komponen signifikan dan tidak signifikan di stasiun 2 dapat dilihat pada (Gambar 7). Komponen yang signifikan pada stasiun 2 berjumlah 11 komponen yaitu $\mathrm{MO}_{3}, \mathrm{MK}_{3}, \mathrm{SK}_{3}, \mathrm{M}_{4}, \mathrm{MS}_{4}, \mathrm{~S}_{4}, 2 \mathrm{MK}$, $2 \mathrm{SK}_{5}, 2 \mathrm{MS}_{6}, 2 \mathrm{SM}_{6}$ dan $\mathrm{M}_{8}$ dengan nilai yang bervariasi setiap komponenya. Komponen yang tidak signifikan di stasiun 2 terdapat 4 komponen yaitu $\mathrm{MN}_{4}, 2 \mathrm{MN}_{6}$, $\mathrm{M}_{6}$ dan $3 \mathrm{MK}_{7}$ dengan nilai yang bevariasi setiap komponen pasang surut peraiaran dangkal, hal ini dikarenakan komponen yang tidak signifikan pada stasiun 2 lebih sedikit mengalami gangguan/ error.

Nilai komponen signifikan dan tidak signifikan di stasiun 3 dapat dilihat pada (Gambar 8). Komponen yang signifikan pada stasiun 3 berjumlah 11 komponen yaitu $\mathrm{MO}_{3}, \mathrm{MK}_{3}, \mathrm{SK}_{3}, \mathrm{MN}_{4}, \mathrm{M}_{4}, \mathrm{SN}_{4}, \mathrm{MS}_{4}, \mathrm{~S}_{4}$, $2 \mathrm{MK}_{5}, 3 \mathrm{MK}_{7}$ dan $\mathrm{M}_{8}$ dengan nilai yang bervariasi setiap komponenya. Komponen yang tidak signifikan di stasiun 2 terdapat 5 komponen yaitu $2 \mathrm{SK}_{5}, 2 \mathrm{MN}_{6}$, $\mathrm{M}_{6}, 2 \mathrm{MS}_{6}$ dan $\mathrm{M}_{8}$ dengan nilai yang bevariasi setiap komponen pasang surut perairan dangkal, hal ini dikarenakan komponen yang tidak signifikan pada stasiun 3 lebih sedikit mengalami gangguan/ error.

Berdasarkan Gambar 7 dan Gambar 8 diketahui bahwa pada stasiun TPI Sungai Rengas dan BMKG Maritim Pelabuhan Dwikora merupakan stasiun terbanyak yang memiliki jumlah komponen signifikan sebanyak 11 komponen. Hal ini disebabkan pada stasiun 2 dan 3 lebih banyak terdistorsi dan menghasilkan komponen pasang surut perairan dangkal signifikan yang relatif lebih banyak dibandingkan di Muara Jungkat, sedangkan untuk komponen pasang surut yang tidak signifikan berlokasi di Muara Jungkat berjumlah 7 komponen dengan nilai yang bervariasi. Hal ini dikarenakan nilai amplitudo errornya lebih besar sehingga komponen yang tidak signifikan lebih banyak terjadi di Muara Jungkat.

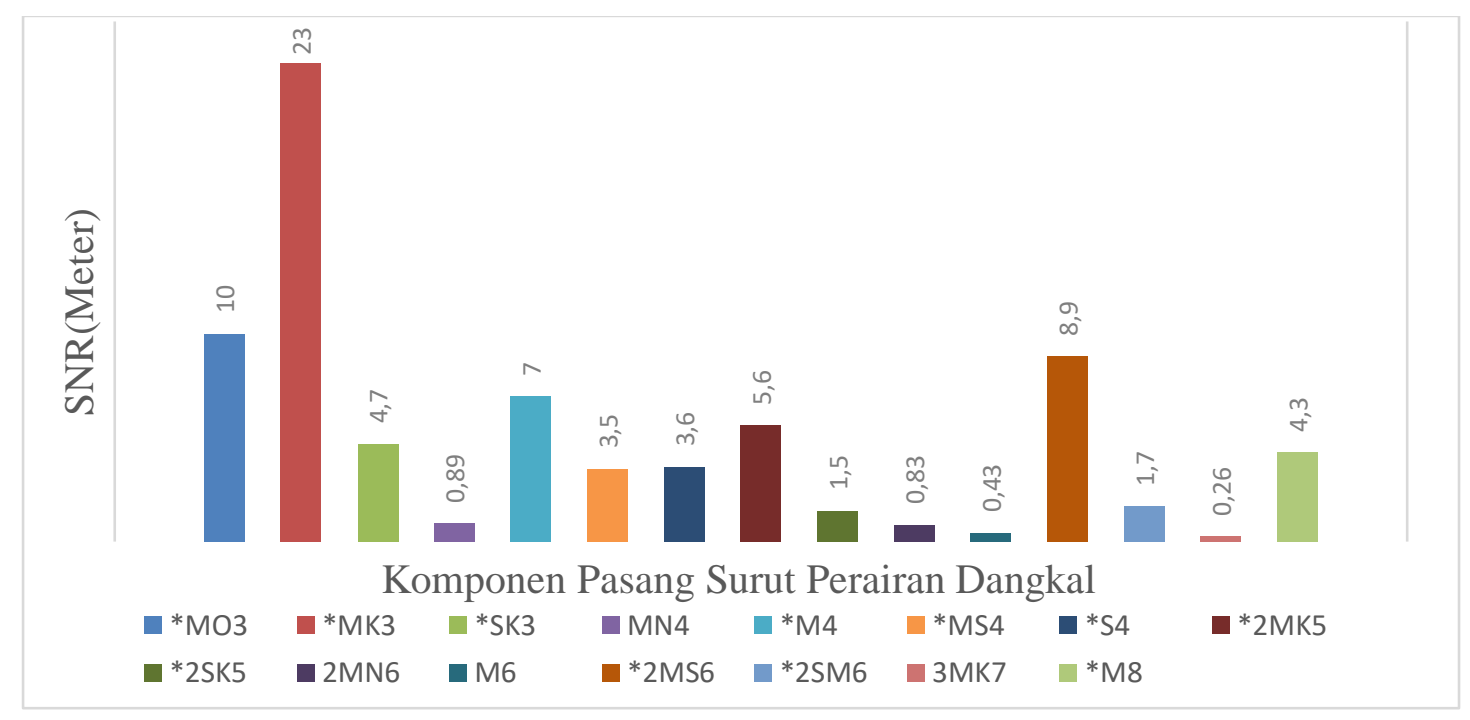

Gambar 7. Komponen pasang surut perairan dangkal yang signifikan dan tidak signifikan di TPI Sungai Rengas 


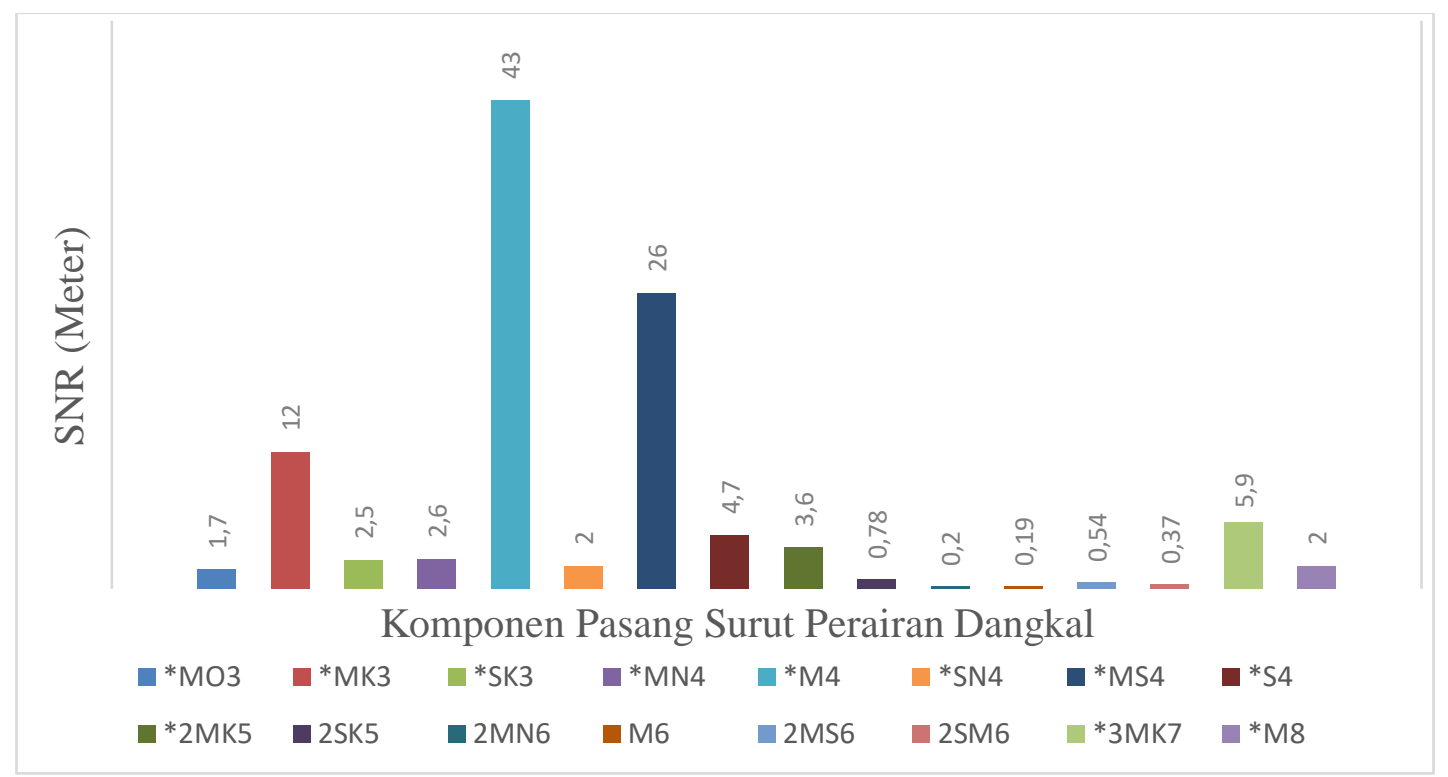

Gambar 8. Komponen pasang surut perairan dangkal yang signifikan dan tidak signifikan di BMKG Maritim

\section{Kesimpulan}

Kesimpulan yang diperoleh dari penelitian ini adalah:

1. Nilai amplitudo tertinggi pada komponen $\mathrm{MO}_{3}$ dengan nilai 0,0217 meter dan nilai amplitudo terendah terdapat pada komponen $\mathrm{MN}_{4}$ dengan nilai 0,0018 meter yang berlokasi di Muara Jungkat. Nilai amplitudo tertinggi pada komponen $\mathrm{MK}_{3}$ dengan nilai 0,0353 meter dan nilai amplitudo terendah pada komponen $\mathrm{M}_{6}$ dengan nilai 0,0019 meter yang berlokasi di TPI Sungai Rengas. Nilai amplitudo tertinggi terdapat pada komponen $\mathrm{MK}_{3}$ sebesar 0,0269 meter dan nilai amplitudo terendah terdapat pada komponen $\mathrm{MN}_{6}$ dan $\mathrm{M}_{6}$ dengan nilai 0,0022 meter yang berlokasi di BMKG Maritim.

2. Nilai Fase tertinggi pada komponen $3 \mathrm{MK}_{7}$ sebesar $355,71^{\circ}$ dan komponen $2 \mathrm{MN}_{6}$ merupakan fase terendah dengan nilai $18,53^{\circ}$ yang berlokasi di Muara Jungkat. Nilai fase tertinggi pada komponen $2 \mathrm{MS}_{6}$ dengan nilai $333,33^{\circ}$ dan nilai fase terendah terdapat pada komponen $\mathrm{M}_{4}$ yang

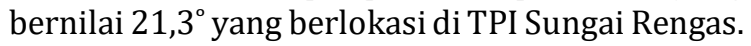
Komponen $2 \mathrm{MS}_{6}$ merupakan fase tertinggi dengan nilai $357,46^{\circ}$ dan fase terendah bernilai $15,47^{\circ}$ dengan komponen $\mathrm{M}_{6}$ yang berlokasi di BMKG Maritim.

3. Komponen dengan Nilai signifikan terbanyak terdapat di stasiun 2 dan 3 yang berlokasi di TPI Sungai Rengas dan BMKG Maritim. Nilai signifikan yang terkecil terdapat di stasiun 1 yang berlokasi di Muara Jungkat.

\section{DAFTAR PUSTAKA}

(1) Adjie, S., dan Dharyati, E., 2009. Sebaran Dan Kebiasaan Makan Beberapa Jenis Ikan Di Daerah
Aliran Sungai Kapuas, Kalimantan Barat. BAWAL., 2:283-290. Palembang.

(2) Jumarang, M.I., Muliadi., Ningsih, N.S., Hadi, S., \& Martha, D., 2011. Pola Sirkulasi Arus dan Salinitas Perairan Estuari Sungai Kapuas Kalimantan Barat. POSITRON.1(1):36-42.

(3) Basith, A., dan Prakoso, Y., 2015. Kontribusi Konstanta Pasang Surut Perairan Dangkal Terhadap Pasang Surut di Sekitar Pulau Jawa. FIT ISI, 2(1).

(4) Lindawati., 2018. Karakteristik Perambatan Gelombang Pasang Surut di Estuari Kapuas Kecil. Universitas Tanjungpura, Fakultas Matematika Dan Ilmu Pengetahuan Alam Pontianak (skripsi).

(5) Hozlinde, L., Badewien, T. H., Freund, J. A., Stanev, E. V., \& Zielinski, O., 2015. Processig of water level derived from water pressure data at the Time Series Station Spiekeroog. Earth System Science Data, 7, 289-297.

(6) Pawlowicz, R., Beardley, B., dan Lentz, S., 2002. Classical Tidal Harmonic Analysis Including Error Estimates in MATLAB Uing T_TIDE, Computers \& Geosciens, 28(8): 929-937.

(7) Leffler., Keith, E., Jay., David, A, 2008. “Enhancing tidal harmonic analysis: Robust (hybrid L1=L2) solutions", Continental Shelf Research.

(8) Harjiono, SWB. 2007. Kenaikan Tinggi Muka Laut Akibat Fenomena Alam. Departemen Komunikasi dan Informatika Republik Indonesia, Jakarta, Kominfo-Newsroom.

(9) Kamshory, 2014. Simulator Posisi Matahari Dan Bulan Berbasis Web Dengan Webgl. Jurnal Nasional Teknik Elektro. 3(2): 182-189

(10) Suraina., Arman, Y., \& Lapanporo, B. P., 2015. Simulasi Orbit Planet Dalam Tata Surya Dengan 
Metode Euler, Leapfrog Dan Rung-Kutta. PRISMA FISIKA. 3(2):69-74.

(11) Sumotarto. U. 2007. Pemanfaatan Energi Pasang Surut. Jurnal Saint dan Teknologi BPPT, Jakarta.
(12) Padil , H. A., 2013. Dasar-Dasar Ilmu Falak Dan Tataordinat Bola Langit Dan Peredaran Matahari, 2(2):196 